\title{
RESEARCH ON THE HIGH-METAMORPHIC COMPLEXES \\ OF THE AGTO AREA
}

\section{E. Bondesen}

Mapping in the Agto area was continued in 1967, the second season of new research in this area; five teams were in the field mapping in nine individual areas. The main object of the mapping is to elucidate the relations between the Isortoq granulite facies complex in the south and the amphibolite facies gneisses of the Egedesminde complex in the north (Ramberg, 1949). Already from the first field season (Bondesen, 1966, p. 20) it was clear that the problem essentially concerned areas with contrasted tectonic development and style besides metamorphic history and degree.

The work is part of a university research project which has received financial support from the Research Foundation of the University of Aarhus as well as continued support from the Carlsberg Foundation. The work also forms part of the Survey's mapping programme and the results will appear in a Survey 1:100 000 sheet.

The mapping this year was extended to the east to the interior parts of Ataneq fjord, to the south to Gamle Egedesminde and Gieseckes $S \phi$ and, to complete the structural picture, locally north of $68^{\circ}$ which otherwise forms the northern limit of the 1:100000 sheet. In addition most of the numerous skerries and islands south-west of Agto village were mapped.

The structural picture obtained in 1966 has been supported by new details but some modifications seem to be necessary. It is opportune now to establish three main structural units in the area:

1) An upper structural unit consisting of metasediments - marbles, granulite s.s., garnet-mica schists, graphite schists, quartzites and amphibolites. This structural unit always occurs synformally.

2) A lower structural unit of banded amphibolites in a very complex fold pattern.

3) Another lower structural unit, consisting mainly of agmatites, which rarely shows fragments of larger structures. 
The folding of all three units is controlled by ENE-trending axes refolded by NW-trending steeply plunging fold axes. However, the lower structural units show a more complex development due to additional fold phases.

In the north and also in the south of the area mapped until now a different regional structural pattern occurs, as the upper structural unit in these localities occurs tightly down-folded in between long NNE-trending zones of rocks belonging to agmatitic unit (3) mentioned above. The southern border of the area mapped to date is a thrust zone of major importance which runs along Gieseckes $S \phi$ towards the inner part of Ataneq fjord.

A variety of granitic rocks occur in the western part of the area, mainly in the skerries. There are both autochthonous and late allochthonous members with different lithlogical characters. A foliated hornblende-garnet granite and a microcline-porphyroblastic granite, also with hornblende and garnet, are thought to be autochthonous, whereas a homogeneous biotite granite in cross-cutting sheets represents an allochthonous phase.

The granites frequently have conformable contacts to the metasediments of the upper structural unit as well as to nebulites and agmatites belonging to the lower units.

In one case - on Nunarssuaq island - the transgressive border zone of an autochthonous granite appears to cut through a synformal structure belonging to the upper structural unit. The border zone is characterized by increasing microcline porphyroblastesis and granite veining towards the granite.

As mapping progressed more and more metadykes were discovered. The dykes are amphibolites, pyribolites and garnet amphibolites, and sometimes mafic biotite gneiss bodies. They may be grouped as:

a) rectilinear metadykes with well preserved intrusive features,

b) disrupted and folded metadykes with clearly discordant relations to surrounding structures, 
c) disrupted and folded basic bodies concordant or subconcordant to the surrounding structures,

d) ghostly cross-cutting metadykes.

To these may be added other types which, however, are only known as isolated phenomena.

The differences in appearance of the dykes may indicate differences in their age, the dykes marking major time intervals between different metamorphic and deformational events. However, it is very suggestive that the distribution of the different groups of dykes corresponds to the distribution of areas of different structural style or different metamorphic development and facies. Thus dykes showing varying degrees of metamorphism and deformation may occupy the same position in the chronology of the area. It seems, however, that no dykes cut the metasediments of the upper structural division.

References

Bondesen, E. (1966) Research on the high-metamorphic complexes of the Agto area. Rapp. Grønlands geol. Unders., Nr. 11, 20-23.

Ramberg, H. (1949) On the petrogenesis of the gneiss complexes between Sukkertoppen and Christianshaab, West-Greenland. Medd. dansk geol. Foren. ,Bd. 11, 312-327. 